\title{
COOPERATION INSTRUMENTS BETWEEN CULTURAL INSTITUTIONS AND THE ENVIRONMENT
}

\author{
Dorota Balcerzyk*
}

\begin{abstract}
Background. Cultural institutions are facing new social challenges today and so in order to be able to manage them, they cannot only rely on their own potential. Implementing common goals can imply undertaking inter-organisational operations. In the literature of the subject there is insufficiency of research on the cooperation of cultural institutions with the environment, that is why this article has highlighted this issue. The paper shows the value of cooperation as a management instrument, thanks to which cultural institutions can increase their potential while performing their tasks more effectively. Reference has pertained to publications on effective cooperation between public institutions and companies.
\end{abstract}

Research aims. The purpose of the research was to diagnose cooperation between cultural institutions and the environment. The main research problem involved looking for answers to the questions: do cultural institutions cooperate with other institutions of this type, located in Wroclaw, to increase their offer directed to early school children? Who is the initiator of the cooperation? What is the form of initiating the cooperation with the other institutions? What is the frequency of undertaking cooperation between cultural institutions and the environment?

Methodology. The issue of cooperation was discussed based on empirical data obtained from the survey conducted in cultural institutions located in Wroclaw. The factor, which connects the researched institutions was to orient their activities to organise free time for children in early school age. The study covered all cultural institutions with an offer addressed to this group of receivers, where the problem questions were aimed to the managers.

Key findings. The analysis of the research indicates that most of the researched institutions undertake cooperative activities. Nonetheless, there are some institutions, which are closed to cooperation with the environment or they rarely undertake the cooperation. The nature of the diagnosed cooperation depends to a large on the extent of the specifics of the examined cultural institution. The results of the

\footnotetext{
" General Tadeusz Kosciuszko Military Academy of Land Forces in Wroclaw. E-mail: dorota.balcerzyk@awl.edu.pl
} 
research indicate the need of increasing the spectrum of activities undertaken by cultural institutions for cooperation with the environment.

Keywords: public organisations, cooperation, public management, cultural institutions.

\section{INTRODUCTION}

Contemporary organisations have to cope with ever-greater social expectations. Among them, institutions of culture play a special role. They belong to organisations carrying out a social mission related to the creation, propagation, and cultivation of cultural heritage of the society in which they function. These are mainly public organisations appointed by state and self-government bodies to carry out specific social tasks. Cultural institutions are public organisations that take action for the common good. The specificity of these institutions lies in the differences in motives for activity taken, characteristics, the system of values and patterns of attitudes and behaviours of the participants of organised activities that influence their management. According to B. Kożuch (2011, pp. 17-18), public organisations, despite their social message, are forced to operate in a market economy. Although the economic aspect is not dominant in the activities of public organisations, it should be taken into account.

Faced with the expectations of civil society, cultural institutions that represent public organisations should revise their management instruments and evolve towards cooperation with the environment, thus to go beyond the framework of their own organisation.

\section{THE ESSENCE OF COOPERATION BETWEEN ORGANISATIONS}

The Polish Language Dictionary defines cooperation as "work performed together with someone, with others, joint work, activity undertaken jointly"(Szy mczak, 2002, p. 715). Cooperation may involve activities carried out jointly by persons, entities, or institutions. J. Lichtarski understands the concept of cooperation more broadly as "undertaking mutually com patible and complementary activities as well as those having a positive effect on the achievement of enterprises' goals". 
Such a statement implies that the harness of the potential of cooperation as a management tool fosters the achievement of the organisation's goals.

According to L. Lichtarski (1992, p. 13), cooperation may involve positive cooperation (cooperation, collaboration), which consists in helping to achieve mutually consistent goals but also negative cooperation (struggle) when organisations aim to achieve contradictory goals. B. Kożuch distinguishes between "two types of interaction:

- cooperation, i.e. activities related to the cooperative attitude and expectation of reciprocity;

- confrontation, that is, activities involving rivalry or fighting, which in practice take different forms of competition" (Kożuch, 2011, p. 110).

Therefore, it should be noted that the concept of cooperation can be seen both in a positive and negative context, i.e. focused on effectiveness, success, values or extension of activity as well as having a pejorative character of interactions with others, e.g. to eliminate competition.

A.T. Himmelman (1996, p. 27; 2002) defines cooperation in relation to three other cooperation strategies: networking, coordination, and cooperation. He understands networking as an exchange of information for the mutual benefit. It is the most informal form of inter-organisational connections, often with a limited level of trust and accessibility. Coordination is also an exchange of information leading to mutual benefit, as well it leads to changing actions and achieving common goals. In comparing to networking, this strategy needs more commitment in the organisation and takes more time. It is characterised by moderate levels of trust and minimal availability of common resources. A.T. Himmelman describes cooperation as an exchange of information, a change of actions and an exchange of resources for mutual benefits and achievement of a common goal. According to the author, cooperation requires more organisational commitment than networking or coordination, because it can include written or even legal contracts. Cooperation may require a considerable amount of time. Furthermore, it has a higher level of trust and considerable access to resources. Resources may include financial, technical, human, and physical (real estate) contributions. It includes knowledge, access to a team of professionals or a real estate. Collaboration is, according to A.T. Himmelmann, a strategy that differs from cooperation on the attitude of the organisation or private persons to enhance the capacity not only of themselves, but also their partners, to achieve 
mutual benefits and to achieve common goals. This definition assumes, that collaborating organisations share the risk, responsibility, and profitability, and each one of them contributes to the partner's ability to grow. Collaboration is characterised by significant commitments, a very high level of trust, and extensive access to partner resources (Himmelman, 1996, pp. 28-30; 2002). It should be emphasised that each of the four strategies may be appropriate in the specific circumstances of the organisation.

The concept of cooperation, collaboration is referred to at least two entities, which are mutually engaged in something (Pszczołowski, 1978, p. 273). Organisations come in a variety of relationships with entities operating in their environment. These can be casual, spontaneous, or partner relations. Defining a partnership as a long-term, relatively stable relationship based on mutual trust and an open exchange of information, as well as the joint share in risks and benefits of interoperability (Himmelman, 2002; Kempny, 2001, p. 280), sets the desired direction for cooperation between institutions.

Observing the specific rules that describe cooperation seems to constitute the foundation of persistent cross-organisational relationships. It is substantial to respect the ethics of cooperation, that is to keep the conditions agreed upon, share information, take mutual care of the partners' benefits, maintain quality and timing regimes and conditions of possible payments. Partnerships should be based on mutual respect, taking into account the customary standards of entities based on mutual goals and interests. Additional long-term cooperation principles include an increase in the organisation's efficiency and flexibility to meet the needs of the recipient, as well as economic viability (Kożuch, 2011, p. 114).

Among the many typologies of cross-organisational relations in the context of behaviours of organisations focused on cooperation, the typology of strategic organisational behaviours according to B. Kożuch (2011, p. 112) has been recognised the best suited to the specificity of cultural institutions. The author describes behaviours such as:

- exchange of information;

- mutual benefit;

- change in forms of action;

- fulfilment of common goals;

- sharing of resources;

- increase in competence. 
Behaviours typical for cooperation-oriented relationships between institutions positively influence the process of collaboration and foster the efficiency and development of cultural institutions. Undoubtedly, the prerequisites taken into account when using such a management instrument i.e. cooperation, are distinct and depend on the type of cultural institution we are dealing with.

\section{CHARACTERISTICS OF CULTURAL INSTITUTIONS}

In Poland, institutions of culture are subject to the provisions of the Act of 25 October 1991 on organising and engaging in cultural activity. According to its provisions they are organisational forms of cultural activity, which within the meaning of this Act consists in the creation, dissemination, and protection of culture. Institutions of culture include: theatres, operas, operettas, philharmonic orchestras, film institutions, cinemas, museums, libraries, culture centres, art centres, art galleries, and research and documentation centres in various cultural fields (Act, 1991). Depending on the accepted classification criterion, a number of types, categories, and subcategories of cultural institutions can be distinguished.

Following the criterion of ownership forms based on the linkage to the ways of establishment, supervision, and funding, cultural institutions can be divided into (NCC, 2017):

- public (government and self-government of three levels - subcategory: province, district, and municipality);

- private;

- civic (NGOs - non-governmental organisations) - cultural associations and foundations;

- mixed categories (e.g. music centres, companies with public capital).

The specialisation of the function allows for dividing cultural institutions into:

1. Mono-functional (profiled, dedicated, repertoire) related to the fields: music; plastic art; film, etc.

2. Educational (art schools of all levels, music centres, training companies, etc.)

3. Multifunctional: culture houses and centres, municipality, district, and province youth culture centres (houses) (Polish MDK), youth palaces, etc. 
Due to the criterion of professionalism the following cultural institutions can be distinguished: professional, semi-professional, and non-professional. In view of the economic assumptions, the commercial criterion can be taken into consideration, hence the division into: commercial and non-commercial cultural institutions. The scale of impact distinguishes cultural institutions: local, environmental, regional, national, and international (global).

The abovementioned divisions are not separable or exhaustive. A particular institution can belong, and often does, to several categories or types depending on the accepted criteria.

Cultural institutions may be lead-managed by both local government units, whose cultural activities are mandatory tasks and can be organised by legal persons, individuals and organisational units without legal personality. Institutions of culture, which are organised by local government units, may receive targeted subsidies for tasks covered by state patronage, targeted subsidies for financing or co-financing investment costs from the state budget in part that is at the disposal of the Minister competent for culture and protection of the national heritage (Act, 1991).

The above characteristics of cultural institutions describing them in terms of criteria of division and financing implies an image of the diversity of these institutions. Undoubtedly, this variety and specificity of the form determines the nature of management of particular institutions. The activity of a mono-oriented institution focused on a chosen recipient, financed by the self-government varies from a multifunctional institution as an economic operator, which satisfies the needs of a broader range of addressees.

\section{COOPERATION BETWEEN CULTURAL INSTITUTIONS IN THE CONTEXT OF RESEARCH}

Regardless of the specificity of a given cultural institution, each of them aims to make its offer as attractive as possible. One way to increase the potential of a cultural institution is to use a management instrument i.e. cooperation with other institutions operating in the immediate and distant environment. Is it, however, used in the management of cultural institutions? This problem was the basis for the diagnosis of cooperation of selected cultural institutions located in Wroclaw. The survey was 
conducted in the year 2014 among the cultural institutions located in Wroclaw, which served a common objective: arranging leisure time activities for children at the early school age.

The research was carried out in: four youth culture houses: the Fabryczna Youth Culture House, the Krzyki Youth Culture House, the Śródmieście Youth Culture House and the Mikołaj Kopernik Youth Culture House (another name of the Center for Cultural Education of Children and Youth) (EIW, 2014); theatres: the Puppet Theatre and the Polish Theatre and musical stages: the Capitol Musical Theatre, the Wroclaw Opera, Witold Lutoslawski Philharmonic (since 2014 the National Forum of Music); museums: the Wrocław City Museum, the National Museum in Wroclaw (and its two branches), the Museum of Post and Telecommunications, and cinemas: Multikino (two branches), Helios, CinemaCity, and New Horizons Cinema. Moreover, the offers of the Wrocław-Zachód Culture Centre, the Agora Culture Centre, the Centennial Hall Discovery Centre, and the Wroclaw ZOO were taken into consideration. In total, 20 cultural institutions located in Wroclaw were surveyed by means of questionnaires addressed to the management of those institutions. The surveys were conducted in the aforementioned institutions from September to December 2014. 90\% filled in questionnaires were returned. The data obtained by the diagnostic survey was supplemented with secondary data analysis - the websites of the institutions of culture (CMW, 2014; KYCH, 2014; MNW, 2014; NCC, 2017; NFM, 2014; OW, 2014; SYCH, 2014; YCHW, 2014).

One of the research objectives was to determine whether cultural institutions cooperate with other such institutions situated within the administrative borders of Wroclaw in order to enrich their offer addressed to early school children. Among the specific problems, there were questions about determining the originator of such cooperation and how often it is undertaken with a given entity. The question about the form of initiating possible cooperation was also recognised as relevant.

The information obtained from the respondents allowed for the conclusion that all the investigated cultural institutions indicated at least one institution they cooperated with. In the questionnaires, the respondents gave 54 names of institutions (among which individual primary and lower secondary schools and kindergartens were not counted separately). In total, as for the questions about the originator 
of cooperation and its frequency, institutions were mentioned 133 times. The institutions they cooperated with were categorised and the data are presented in Table 1.

Table 1. Cooperation of cultural and educational institutions with other institutions to enrich the offer addressed to children at the early school age

\begin{tabular}{|c|c|c|c|c|c|c|c|c|c|}
\hline \multirow{3}{*}{$\begin{array}{l}\text { Categories of } \\
\text { institutions } \\
\text { indicated }\end{array}$} & \multirow{3}{*}{$\begin{array}{l}\text { Number of } \\
\text { indications }\end{array}$} & \multirow{2}{*}{\multicolumn{2}{|c|}{$\begin{array}{l}\text { Initiator of } \\
\text { cooperation }\end{array}$}} & \multicolumn{6}{|c|}{ Frequency of cooperation } \\
\hline & & & & \multicolumn{2}{|c|}{$\begin{array}{c}\text { Most } \\
\text { frequent } \\
\text { cooperation }\end{array}$} & \multicolumn{2}{|c|}{$\begin{array}{l}\text { Permanent } \\
\text { cooperation }\end{array}$} & \multicolumn{2}{|c|}{$\begin{array}{l}\text { Occasional } \\
\text { cooperation }\end{array}$} \\
\hline & & l.b. & $\%$ & l.b. & $\%$ & l.b. & $\%$ & l.b. & $\%$ \\
\hline $\begin{array}{l}\text { Schools, care centres } \\
\text { and educational } \\
\text { institutions }\end{array}$ & 43 & 12 & 60 & 14 & 70 & 9 & 45 & 4 & 20 \\
\hline Museums & 24 & 10 & 50 & 9 & 45 & 4 & 20 & 2 & 10 \\
\hline $\begin{array}{l}\text { Theatres and music } \\
\text { scenes }\end{array}$ & 16 & 3 & 15 & 2 & 10 & 7 & 35 & 5 & 25 \\
\hline $\begin{array}{l}\text { Higher education } \\
\text { institutions and } \\
\text { artistic schools }\end{array}$ & 13 & 0 & 0 & 4 & 20 & 8 & 40 & 2 & 10 \\
\hline $\begin{array}{l}\text { Scientific and } \\
\text { culture centres }\end{array}$ & 11 & 1 & 5 & 2 & 10 & 5 & 25 & 1 & 5 \\
\hline $\begin{array}{l}\text { Foundations and } \\
\text { associations }\end{array}$ & 10 & 0 & 0 & 7 & 35 & 2 & 10 & 3 & 15 \\
\hline Libraries & 9 & 3 & 15 & 4 & 20 & 1 & 5 & 2 & 10 \\
\hline Cinemas & 5 & 3 & 5 & 1 & 5 & 1 & 5 & 1 & 5 \\
\hline $\begin{array}{l}\text { Sports centres and } \\
\text { others }\end{array}$ & 4 & 0 & 0 & 1 & 5 & 0 & 0 & 1 & 5 \\
\hline Total & 133 & & & & & & & & \\
\hline
\end{tabular}

Source: own study $(\mathrm{N}=20)$.

In reply to questions related to cooperation the most frequently indicated institutions were schools, care centres, and educational institutions (43 indications). Among the mentioned ones are primary schools from the area of Wroclaw and Lower Silesia, junior high schools (Polish gimnazjum) and Secondary School No. 1 (18 indications). The respondents claimed that they even had a database of schools with which they cooperate.

The reported cooperation with schools was based on the preparation of art workshops, thematic classes, joint preparatory work for end-of-the-year galas and, as the respondents said, students' visits or lessons ordered regularly. In this category, there were also public 
and non-public kindergartens and pre-school points (7 indications) for which the respondents prepared workshops, attractions at the cinemas for children and parents, the Pre-School Theatre Festival in the Agora Culture Centre. The respondents frequently cooperated with the Youth Culture Houses (12 recommendations) by co-organising events, competitions, tournaments, presentations between the Agora Youth Culture House, the Zachód Youth Culture House, and the Fabryczna Youth Culture House or the exhibition of Christmas cribs made by participants of the Śródmieście Youth Culture House held by the Ethnographic Museum.

Their databases of the partners also contained day centres and non-governmental organisations (3 indications) that organise day camps at the Museum of Post and Telecommunications in Wroclaw during the winter holidays and summer holidays. In addition, the respondents pointed to the cooperation with the Lower Silesian Special Purpose School and Educational Centre No. 12 for Blind and Poor-Sighted Children in Wroclaw (2 indications) and the Lower Silesian Specialised School and Educational Centre for the Deaf and Hearing Impaired (1 indication).

Frequently mentioned institutions, which the respondents cooperated with so as to enrich the offer for children at the early school age are museums (24 indications). According to the surveyed, cooperation with museums consisted in visiting exhibitions organised in museums and presenting works by young artists. The cooperation with the following museums was pointed out: located in Wroclaw the National Museum, the City Museum, the Museum of Post and Telecommunications, the Museum of Architecture, the Museum of Modern Art, the City Gallery, and located outside the city - the Museum of Paper Industry in Duszniki (the participation in the presentation of the production of hand-made paper during the "Letter Festival" event was declared), the Museum of Carriages in Galowice, and the Automotive Museum of Topacz (during outdoor events such as "Stagecoach Day" or "Wroclaw Corso".

Another group of institutions, frequently indicated by the respondents as partners, was theatres and music scenes (16 indications). The Puppet Theatre (8 indications), theatres in general (3 indications), the Wroclaw Philharmonic (2 indications), the Impart Festival Office (1 indication) - unfortunately the character of the interoperation was not added to these institutions. On the other hand, it is known that 
the cooperation with the Polish Theatre ( 1 indication) consists in borrowing props, and with the amateur Korba Theatre (1 indication) in the participation of performances during events like the "Letter Festival" and the "Long Night of Museums".

Universities and art schools were often referred to as a group of institutions with which the surveyed were affiliated (13 indications). Among them there were the Wroclaw University (2 indications) and the Confucius Institute at the University of Wroclaw (2 indications) without specifying the nature of cooperation.

In addition, the respondents have undertaken artistic cooperation with many schools of artistic specialisations (1 indication each): the Academy of Fine Arts in Wroclaw, the Higher State Theatre School in Wroclaw, the State Academy for Cultural Animators and Librarians in Wroclaw, music schools in Wroclaw, students from the percussion class of the Karol Szymanowski Secondary Music School 1st and 2nd degree in Wroclaw, the Boys' Choir, the Ballet School at the Lower Silesian Operetta, the Cracovia Danza Court Ballet in Cracow, as well as Brotherhood and knight teams.

Scientific and culture centres were the category of institutions, which the surveyed had cooperated with to improve the offer for children, and the number of which (11) is the median of the indications of the other categories. Among the category of scientific and culture centres, the ZOO and Humanitarium (3 indications each) were most frequently mentioned, without specifying the type of interoperation. What is more, they indicated individually cooperation with the Botanical Garden and the Centennial Hall Discovery Centre, which had organised activities for children, the Wroclaw Technology Park, the Culture and Art Centre in Wroclaw and the Wroclaw Centre for Children's Creativity, which supported institutions in promotional terms.

More seldom the respondents pointed to foundations and associations (10 indications) as cooperating institutions. In the category of foundations and associations, the Foundation for the Audio Description Development KATARYNKA mentioned by two respondents was included, as well as other institutions indicated only once: the Animals' Friends Foundation, the Foundation "Children's University of Interesting History", the Bente Kahan Foundation (Wroclaw Synagogue), the Association for Children and Youth, the Wroclaw Gallery of Young People, the Polish-Chinese Association for Culture and Art, the Karłowice-Różanka Housing Estate, and the Osobowice-Rędzin Housing Estate Board. 
Relatively often the respondents reported Wroclaw libraries (9 indications) as their partners. The City Library - Mediateka (8 indications), where the vernissages or the promotion of educational projects took place, was mentioned most frequently. Cooperation with the Ossolineum Library in Wroclaw, where lectures and readings were organised during the "Letter Festival", was mentioned as well.

Only five respondents indicated cooperation with cinemas without describing its character. Sports centres and other institutions (a total of 4 indications) were the smallest group among the indicated categories of institutions with which cooperation had been established. These were: WKS Ślask Wroclaw with which meetings with football players were organised before performances for children or tickets for football matches were sponsored for participants of the performances at the City Stadium in the Family Area; the Wroclaw Water Park - a sponsor of prizes for schools in competitions; sports centres and the Bookshop "Train to Fairy Tale".

The conducted research allowed for the identification of the state of cooperation between cultural institutions located in Wroclaw. It can be stated that the respondents declared such cooperation; they indicated institutions with which they cooperated. However, this kind of cooperation leaves a certain feeling of insufficiency. Certainly the cooperation declared by the respondents cannot be defined as collaboration. It is actually taking action to achieve a common goal of the arrangement of free-time activities for early school children, but most often these activities are limited to participating in another institution's offerings or direct profit-making, such as free tickets. Only sometimes the surveyed pointed to the use of shared resources, the potential of the building, the staff (presentation of own works at the partner's place, performances on the partner's stage, promotion of educational projects). Rarely, however, was the collaboration they declared a joint action, a long-term undertaking involving the personnel's engagement in a specific project. The only institutions that showed such cooperation were the youth culture houses located in Wroclaw.

When specifying the cooperation of institutions, one means the category of its time and frequency. Desired cooperation seems to be a long-term relationship. It is therefore important to identify the frequency of cooperation between cultural and scientific institutions undertaken to enrich their offer for early school children. The data collected from the respondents are summarised in Figure 1 and included in Table 1. 


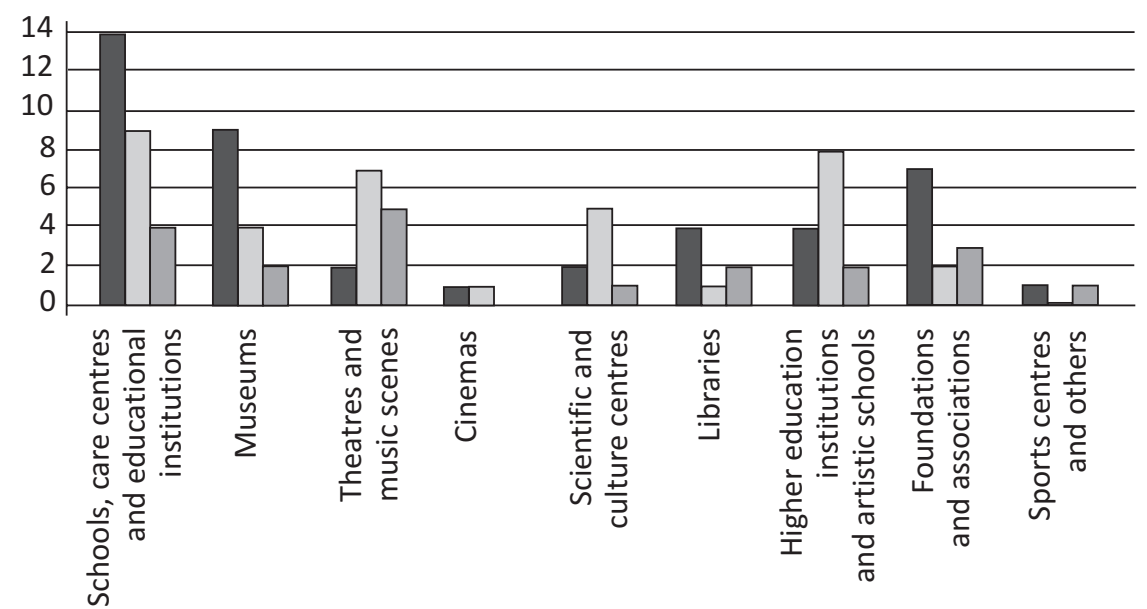

Most frequent cooperation $\quad \square$ Constant cooperation $\quad \square$ Occasional cooperation

Figure 1. Frequency of cooperation within the arrangement of leisure time activities for early school children, depending on the category of cultural and scientific institutions (multiple choice question)

Source: own study $(\mathrm{N}=20)$.

The vast majority of the respondents (70\%) indicated schools and care and educational centres as the institutions they had most often coworked with. Nearly half of the respondents (45\%) mentioned museums in this group, and $35 \%$ of them indicated foundations and associations. Libraries, universities, and art schools were indicated by only one fifth of the respondents as the institutions with which cooperation had most often been undertaken. Theatres and music scenes as well as scientific and culture centres received $10 \%$ indications each as institutions most frequently chosen for cooperation. Cinemas and sports centres were the least frequently mentioned institutions involved in cooperation.

A partner to whom one can always turn to and who is constantly present in our database of co-operators is valuable. Schools, care centres, and educational institutions - as noted by the respondents in personal comments - were most often indicated (45\%) as partners. Among the regular collaborators, the respondents pointed to higher education institutions and artistic schools at the second place (40\%), and at the third (35\%) - theatres and music scenes. Then, subsequently, scientific and culture centres (25\%), museums (20\%), and foundations and associations (10\%) were mentioned as permanent partners. Cinemas and libraries were the least cited (5\% each). Sports centres 
were not identified as institutions with which permanent cooperation had been established.

It happened that in order to make the offer prepared for early school children more attractive, the researched undertook occasional cooperation with various institutions. Theatres and music scenes (25\%), schools, care and education centres (20\%) as well as foundations and associations (15\%) were the most frequent occasional partners. Museums, libraries, higher education institutions, and artistic schools (10\% each) were sporadically listed among the occasional collaborators. Scientific, culture, and sports centres received the lowest number of indications. In contrast, cinemas were not selected as occasional partners.

Schools, care centres and educational institutions (27 indicators) seem to be reliable cooperative partners, as well as museums (15 indications), since they dominated as partners in terms of the frequency of cooperation. Afterwards, the participants listed theatres and musical scenes as well as higher education institutions and artistic schools (14 indications each). As for cooperation cinemas and sports centres were individually mentioned institutions ( 2 indications each).

The initiator of the cooperation, an institution that initiates and attempts to establish contact, seems to be valuable in the world of competition and financial problems faced by cultural institutions. More and more often, cultural institutions treat one another as market competitors, not as partners or the potential that when combined may increase profitability. This assumption implied another specific problem, which was the question about the initiators of cooperation in order to enrich the offer targeted at early school children selected from cultural and educational institutions and schools. The data obtained from the answers to this question are presented in Table 1 and illustrated in Figure 2.

According to $60 \%$ of the respondents, primary schools and care centres and educational institutions were the initiators of cooperation in terms of the arrangement of leisure time activities for early school-aged children. Half of the surveyed cited also museums as the initiators of such cooperation. Museums appeared to be not only very active institutions of culture and science in terms of preparing offers for children, but they approached the expectations of children, parents, or other institutions. Only 15\% of the respondents indicated 
that theatres and music scenes were the originators of cooperation in the organisation of forms intended for early school children. The same percentage of respondents indicated libraries as the initiator of cooperation in this area, and only $5 \%$ of respondents - cinemas and scientific and culture centres. In the respondents' indications concerning the initiators of cooperation within organising free time activities for early school children, the higher education institutions and artistic schools, foundations and associations, and sports centres were omitted.

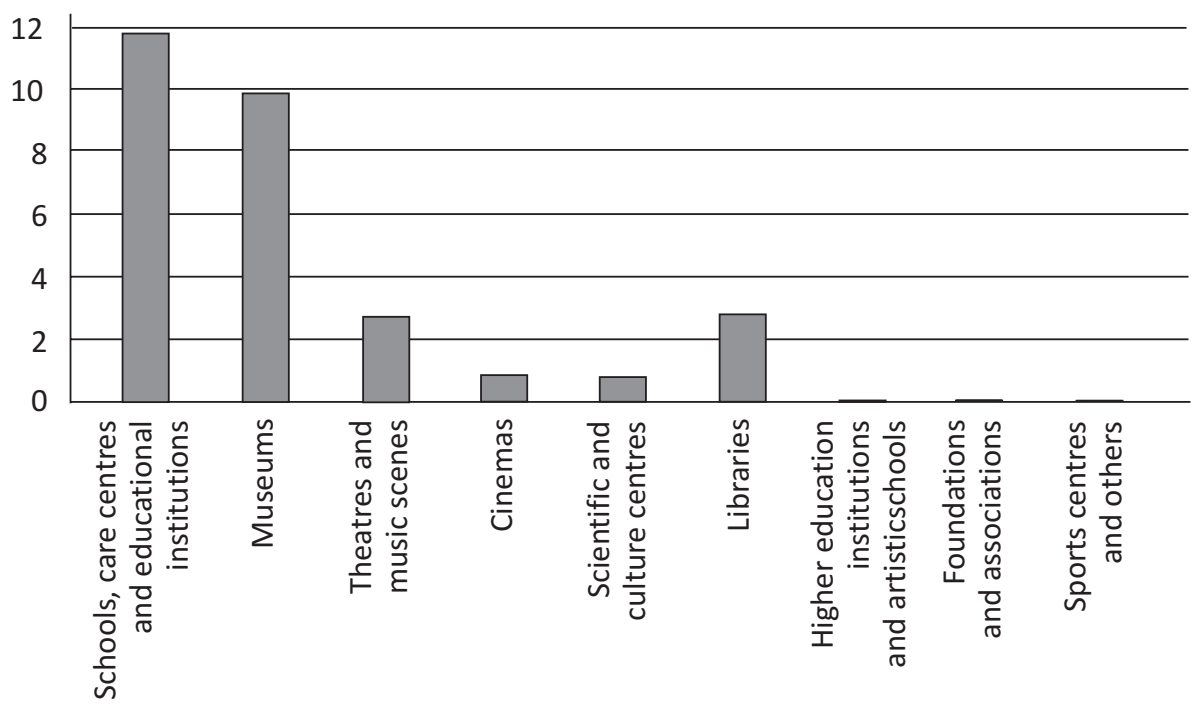

Figure 2. Initiators of cooperation with the surveyed within the arrangement of leisure time activities for early school children (multiple choice question)

Source: own study $(\mathrm{N}=20)$.

It also seemed important to become familiar with the forms of cooperative proposals that the respondents used to establish contact with the intention to cooperate. Figure 3 shows the responses to the question about the forms by means of which the institutions of culture and science received from others proposals on cooperation concerning organising leisure activities for early school children. The respondents were asked to indicate the forms in the cafeteria or to add other forms not proposed. The most common form of cooperation proposed by the respondents turned out to be contact by e-mail - the choice of $80 \%$ of the respondents. 


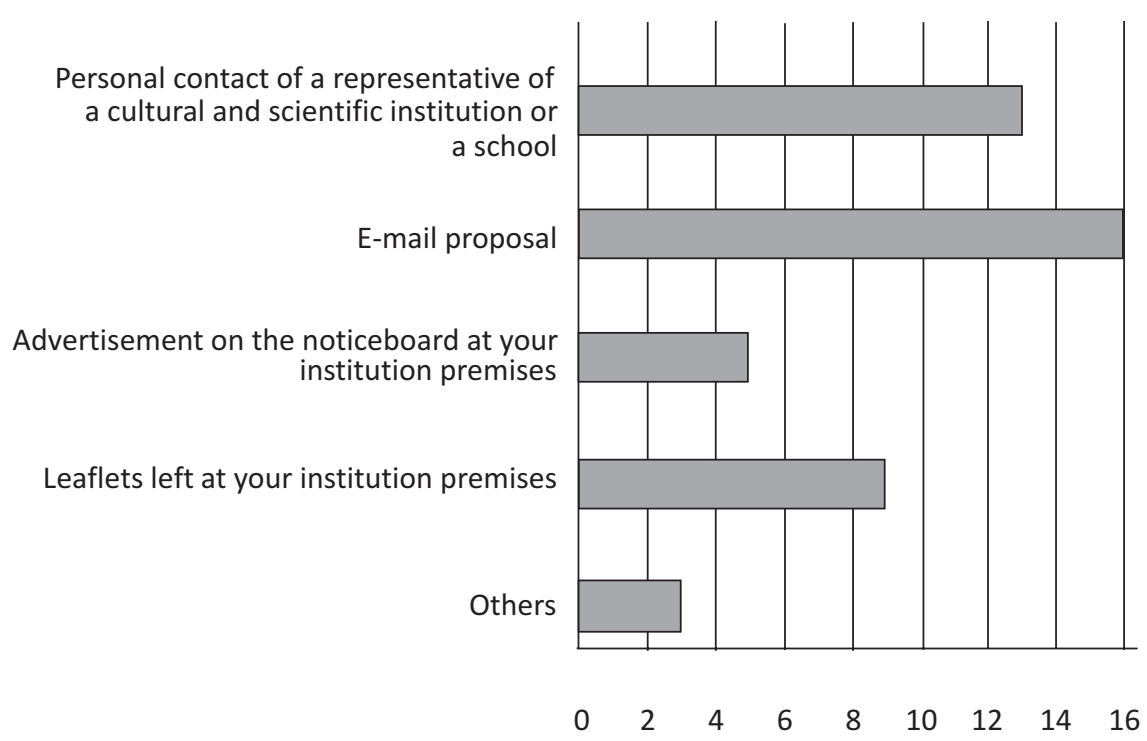

Figure 3. Forms of collaborative proposals by cultural and educational institutions in terms of the arrangement of leisure time activities for early school children (multiple choice question)

Source: own study $(\mathrm{N}=20)$.

It was followed by the personal contact of a representative of a cultural and academic institution or a school with their institution (65\% of the respondents). Almost half of the surveyed experienced cooperative proposals from other institutions in the form of leaflets left at their premises. One quarter of the respondents received offers from other cultural and educational institutions or schools in the form of an advertisement displayed on the noticeboard located in their area. In response, other respondents supplemented the forms proposed by the cafeteria with telephone contacts - which was made by $15 \%$ of the respondents.

By analysing the obtained information on the forms of initiation of cooperation from other cultural institutions than the surveyed group on the organisation of leisure time for early school children, the dependency of these forms on the category of examined institutions was taken into consideration. As it can be seen in Figure 4, youth culture houses experienced only three forms of collaborative proposals for organising free time activities for early school children from other institutions. These were mail proposals, leaflets left in their institution, and telephone contacts. 


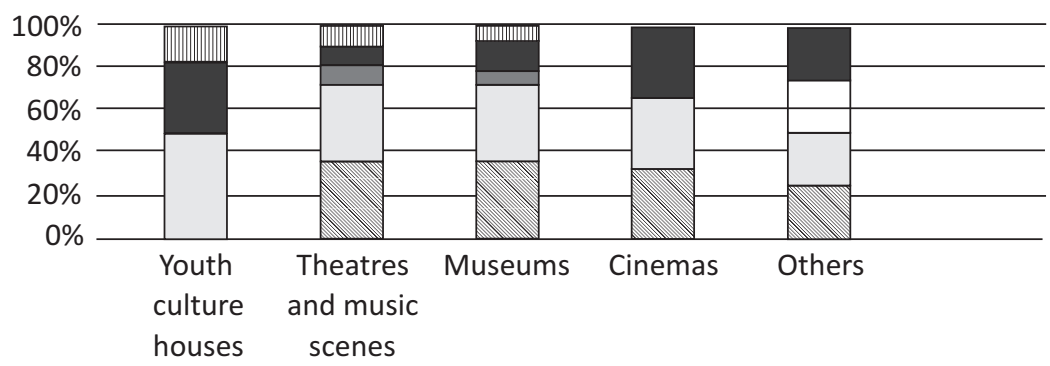

血 Telephone contact

$\square$ Leaflets left at your institution premises

Advertisement on the noticeboard at your institution premises

E-mail proposal

Personal contact of a representative of the cultural and scientific institution or school

Figure 4. The dependence of the proposed forms of collaboration on the part of other cultural institutions from the category of the institutions studied

Source: own study, Wroclaw 2014.

Likewise, cinemas showed only three forms in which other institutions offered them cooperation. This was a personal contact between a representative of a cultural and educational institution or a school, an e-mail proposal and leaflets left at their institution premises. The institutions from the Others category were asked to cooperate according to the four forms offered in the cafeteria: leaflets in their area, advertisements on the noticeboard, e-mail proposals, and the personal contact of a representative from the institution initiating cooperation.

On the other hand, in the most varied forms - potential cooperators turned to theatres and music scenes as well as museums in Wroclaw, as those that had added telephone contacts to the forms proposed.

Which of the forms of the initiation of cooperation within leisure time activities arranged for early schoolchildren did the respondents consider as the most appropriate? Table 2 presents the data obtained from answers to this question. The responses were very similar to the forms of cooperation offered. The most preferable forms were the same as in the case of the previous research problem, but the order of their importance was slightly different. The respondents considered the personal contact of a representative of another cultural and scientific institution or school as definitely the most appropriate form 
of initiating cooperation. About a half of the weight of the proposal is an e-mail proposal, which came second among the most appropriate forms of cooperation proposals. In the third place, leaflets left at the premises of the examined institutions were placed.

Table 2. Forms of the initiation of cooperation in terms of the organisation of leisure time activities preferred by the respondents

\begin{tabular}{|c|c|c|c|c|c|c|c|}
\hline $\begin{array}{ll}\begin{array}{l}\text { Forms of cooperative } \\
\text { proposals }\end{array} & \text { Rank order } \\
\end{array}$ & 1 & 2 & 3 & 4 & 5 & $\begin{array}{l}\text { Calcula- } \\
\text { tions of the } \\
\text { weight }\end{array}$ & $\begin{array}{l}\text { Rank } \\
\text { order }\end{array}$ \\
\hline $\begin{array}{l}\text { Personal contact of a representative of the } \\
\text { cultural and scientific institution or school }\end{array}$ & 19 & 1 & 0 & 0 & 0 & 119 & $\mathbf{I}$ \\
\hline E-mail proposal & 1 & 10 & 0 & 1 & 0 & 59 & II \\
\hline $\begin{array}{l}\text { Advertisement on the noticeboard at the } \\
\text { institution premises }\end{array}$ & 0 & 1 & 1 & 2 & 0 & 15 & IV \\
\hline Leaflets left at the institution premises & 0 & 3 & 5 & 1 & 0 & 38 & III \\
\hline Telephone contact & 0 & 1 & 2 & 0 & 0 & 13 & $\mathrm{~V}$ \\
\hline
\end{tabular}

Source: own study, Wroclaw 2014.

According to the respondents, the less preferred forms of established cooperation included: an advertisement on the noticeboard at the premises of the institution and a telephone contact. Interestingly, in the world of modern technology, the respondents strongly favoured the traditional way of initiating cooperation for the organisation of leisure time activities for children at the early school age, which involved the direct contact of a person representing a given institution.

Who does the idea of establishing cooperation to organise leisure time for early school children come from and who usually begins it? The answers to these questions were obtained by analysing the data presented in Figure 5. 60\% of the respondents claimed that they were the most frequent initiators of cooperation in this area. The group of the respondents - initiators of cooperation can be divided into those who believed that it was launched: only by their institution (12\%), more often by their institution than by other cultural and scientific institutions (16\%), and more frequently by them than by schools. The respondents' answers seem to be understandable given the fact that at the time of designing a new proposal, the originators should have a vision of its implementation, which may, if appropriate, take into account the possible involvement of external institutions. 


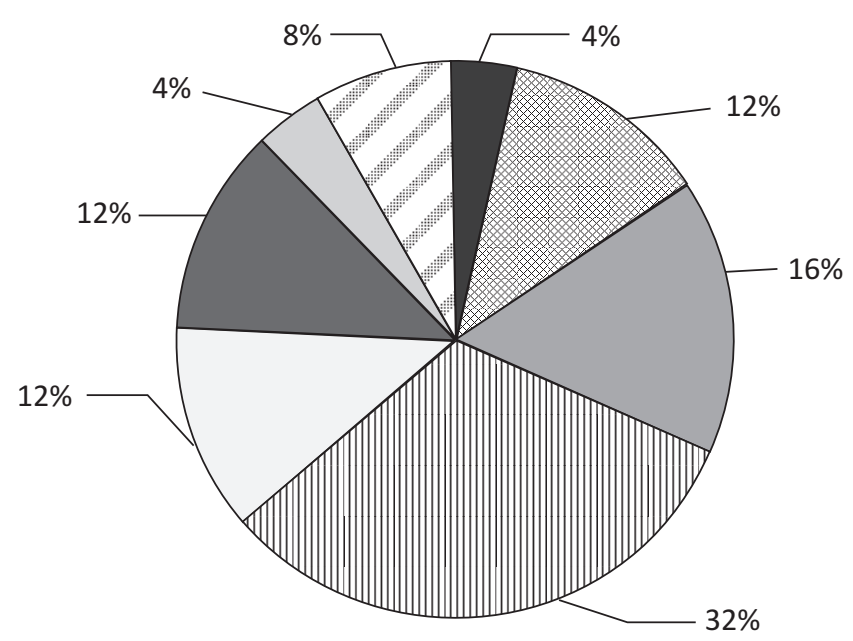

Only your institution

$\square$ More frequently your institution than other cultural and scientific institutions

而 More frequently your institution than schools

$\square$ More frequently other cultural and scientific institutions than your institution

$\square$ More frequently schools than your institution

$\square$ Only other cultural and scientific institutions

Fif Only schools

Other institutions

Figure 5. Initiators of cooperation in terms of the arrangement of leisure time activities for children at the early school age

Source: own study, Wroclaw 2014.

The respondents (40\%) also pointed out that they were not the only initiators of cooperation aimed at free time activities organised for early school children. Among them, $12 \%$ of respondents believed that more frequently the other cultural and scientific institutions were initiators. Also $12 \%$ indicated that schools were more often the initiators. Only $4 \%$ of the surveyed thought that such initiative came exclusively from other cultural and educational institutions; $8 \%$ believed that cooperation was started only by schools, and only $4 \%$ indicated the only initiative on the part of other institutions.

The above data imply the conclusion that cultural and scientific institutions undertake real cooperation based on the reciprocity of initiatives, which is probably dependent on the needs in a given situation and the specificity of offers proposed by them. Furthermore, it allows us to 
believe that the surveyed institutions are anxious to establish cooperation for a common goal - organising leisure time for children at the early school age. They do not stay with their own offerings within their own institution but address initiatives of other institutions whose mission is also to take care of shaping a proper model of spending free time by the young generation.

Schools are the most active institutions collaborating with others to organise free time for children at the early school age. This proves that school leaders whose main task is education, knowledge transfer, and organisation of teaching make additional efforts. Free time care for pupils is a secondary function - not a priority. However, as the research evidences, teachers often maintain a network of contacts with cultural institutions and not only in the environment in which a given school is located.

More common is the frequent cooperation between care and educational centres, i.e. youth culture houses, community centres and non-governmental organisations. The mission of institutions of this kind is to take care and inculcate norms and cultural patterns approved by the society within which they function. Hence the management boards of these institutions direct their activities towards seeking contacts with institutions located in their environment. The cooperation of care and educational centres includes activities that involve not only the use of the offerings, but are based on the mutual exchange of experiences, actual cooperation in the preparation of specific events, workshops.

The most surprising is the initiative and the range of activities undertaken for cooperation with the surroundings of the museums in Wroclaw. The cooperation of museums with the environment engages various cultural institutions. The research showed that the museums' openness to cooperation with the environment results in a very rich offer directed to children of different ages.

The results of the conducted research also indicate that there are facilities closed to cooperation with the environment, i.e. those which establish it quite rarely, e.g. cinemas. Such results can be explained by the specificity of these institutions. Cinemas are strictly commercial institutions. During the study, the respondents' comments appeared expressing their doubts on the purposefulness of questions related to cooperation. According to the respondents - their institutions function as competitors in the market, so they do not take an interest in this 
form. The more valuable entities seem those that undertake initiatives and actions aimed at going beyond the boundaries of their institution and opening up to the environment.

\section{CONCLUSION}

This paper attempts to diagnose the public sector that is the cultural institutions in terms of cooperation with the environment in order to enrich their offerings. Cooperation between public institutions seemed to be an important area from the point of view of the use of management instruments and the performance potential of institutions. The research on the cooperation between cultural institutions allows the conclusion that they are more or less open to cooperation. The dimension of the cooperation undertaken is largely dependent on the type of institution. While most cultural institutions are bureaucratic in nature, many of them are committed to the creativity and initiative of their employees, thus becoming more flexible. They vary mainly in: the recipient and the main tasks for which they have been notified.

The carried out diagnostic studies have shown that cultural institutions located in Wroclaw cooperate with other cultural and scientific institutions and schools in order to enrich the forms of organising daytime leisure activities for children of early school education. The most frequently mentioned institutions are primary schools, care centres and educational institutions. The recipients indicate museums, foundations, and associations as institutions with which they cooperate as well. In the opinion of the respondents they are themselves the most common initiator of cooperation with external institutions. The surveyed most often refer to primary schools, care and education centres, and museums in cases when the initiators are external institutions.

When it comes to collaborative proposals, the research has also shown that representatives of cultural institutions most often inform one another by means of e-mail. On the other hand, they prefer direct contact with a specific person, marginalising all sorts of impersonal forms. This is a surprising choice in a computerised and formal world.

The diagnosis of the cooperation of the selected cultural institutions located in Wroclaw proved the use of the management instrument of cooperation. The nature of cooperation undertaken by the surveyed entities is not satisfactory. The conducted research implies the 
assumption that the respondents use their potential too sporadically, which potential could be a source of mutual benefit that results from more than just the use of own reciprocal offerings. Cultural institutions should recognise the power of cooperation, which lies in interoperability, joint enhancing the competences of staff through an exchange of information, and its development through cooperation within common projects. Only few surveyed institutions were able to boast this type of cooperation. According to the respondents, the strength of the instrument, i.e. cooperation, should also be seen in the combination of activities focused on raising funds. Implementing a joint project targeting at the same objective increases the chance for gaining interest and positive evaluation of a potential sponsor.

The research results allow for the determination of priorities for changes in the activities of cultural institutions, which are public organisations. It would be desirable to increase the spectrum of collaboration between cultural institutions towards joint actions and long-perspective projects. It also seems appropriate to make efforts to build and develop lasting relationships between institutions in the immediate vicinity; the relationship not only of a formal character, but also related to building the relational capital (networking).

Undoubtedly, cultural institutions should more often recognise and use cooperation as an instrument for managing an organisation. The management boards of public institutions should be aware of the benefits of cooperating and closing the barriers to using such a valuable instrument.

\section{REFERENCES}

Czarniawski, H. (2002). Współdziałanie potrzebq czasu. Lublin: Norbertinum.

Himmelman, A.T. (2002), Collaboration for a Change: Definitions, Models, Roles and a Collaboration Process Guide. Minneapolis, MN.

Himmelman, A.T. (1996). On the Theory and practice of transformational collaboration: from social service to social justice. In: Ch. Huxham (ed.), Creating Collaborative Advantage. London: Sage Publications.

Jagoda, H. \& Lichtarski, J. (2002). Kilka uwag o stanie i tendencjach w zakresie współdziałania gospodarczego przedsiębiorstw. In: J. Skalik (ed.), Zmiana warunkiem sukcesu. Integracja, globalizacja, regionalizacja-wyzwania dla przedsiębiorstw. Wrocław: Wydawnictwo Akademii Ekonomicznej. 
Kempny, D. (2001). Logistyczna obstuga klienta. Warszawa: PWE.

Kożuch, B. (2011). Skuteczne wspótdziałanie organizacji publicznych i pozarządowych. Kraków: Instytut Spraw Publicznych UJ.

Kożuch, B. \& Kożuch, A. (2008). Podstawy organizacji i zarzadzania. Kraków: Fundacja Współczesne Zarządzanie.

Lank, E. (2007). Collaborative Advantage. London: Palgrave Macmillan.

Lichtarski, L. (1992). Wspótdziałanie gospodarcze przedsiębiorstw. Warszawa: PWE.

Lipka, A. (2004). Wspótdziałanie. Zmierzch rywalizacji pracowników. Warszawa: Difin. Lichtarski, J. (ed.) (1999). Podstawy nauki o przedsiębiorstwie. Wrocław: Wydawnictwo Akademii Ekonomicznej we Wrocławiu.

Pszczołowski, T. (1978). Mała encyklopedia prakseologii i teorii organizacji. WrocławWarszawa-Kraków-Gdańsk: Zakład Narodowy im. Ossolińskich.

Szymczak, M. (ed.) (2002). Stownik języka polskiego. Warszawa: Wydawnictwo Naukowe PWN.

Szacka, B. (2008). Wprowadzenie do socjologii. Warszawa: Oficyna Naukowa.

Sztompka, P. (2012). Socjologia. Analiza społeczeństwa. Kraków: Wydawnictwo Znak.

Act 1991. The Act of 25 October 1991 on organizing and engaging in cultural activity, Art. 1 Chapter 1.

CMW (City Museum of Wroclaw) (2014). http://www.muzeum.miejskie.wroclaw.pl/ (access: 30.11.2014).

EIW (Education in Wroclaw) (2014). http://www.edu.wroclaw.pl/wps/portal/edu-dev/ main22/placowki (access: 28.10.2014).

KYCH (The Krzyki Youth Culture House) (2014). http://www.mdk-krzyki.pl/3/ (access: 30.11.2014).

MNW (National Museum in Wroclaw) (2014). http://www.mnwr.art.pl/ (access: 30.11.2014).

NCC (National Centre for Culture Poland) (2017). http://obserwatoriumkultury.byd. pl/wp-content/uploads/2012/02/Raport-mened\%C5\%BCerowie-kultury-... skr\%C3\%B3t.pdf (access: 21.02.2017).

NFM (National Forum of Music in Wroclaw) (2014). http://www.nfm.wroclaw.pl/ (access: 30.11.2014).

OW (Opera of Wroclaw) (2014). http://www.opera.wroclaw.pl (access: 30.11.2014).

SYCH (The Śródmieście Youth Culture House) (2014). http://www.mdksrodmiescie. wroc.pl/ (access: 30.11.2014).

YCHW (Youth Culture House in Wroclaw) (2014). http://www.mdk.wroc.pl/ (access: 30.11.2014). 


\title{
INSTRUMENTY WSPÓKPRACY INSTYTUCJI KULTURY Z OTOCZENIEM
}

\begin{abstract}
Abstrakt
Tło badań. Przed instytucjami kultury stoją współcześnie nowe wyzwania społeczne. Aby im sprostać, owe instytucje nie mogą opierać się jedynie na własnym potencjale. Realizacja wspólnych celów może implikować podejmowanie działań międzyorganizacyjnych. W literaturze przedmiotu występuje niedobór badań dotyczących współpracy instytucji kultury z otoczeniem, stąd w niniejszym artykule zwrócono uwagę na tę kwestię. W pracy ukazano wartość współpracy jako instrumentu zarządzania, dzięki któremu instytucje kultury mogą zwiększać swój potencjał, sprawniej realizując zadania, do których zostały powołane. Odniesiono się do publikacji dotyczących skutecznej współpracy pomiędzy instytucjami publicznymi i przedsiębiorstwami.
\end{abstract}

Cel badań. Celem podjętych badań było zdiagnozowanie współpracy pomiędzy instytucjami kultury i otoczeniem. Główny problem badawczy wiązał się z poszukiwaniem odpowiedzi na pytania: czy instytucje kultury podejmują współpracę z innymi tego typu instytucjami położonymi na terenie miasta Wrocławia w celu wzbogacenia swojej oferty skierowanej do dzieci wczesnoszkolnych? Kto jest inicjatorem podejmowanej współpracy? Jaka jest forma inicjowania współpracy z innymi placówkami? Jaka jest częstotliwość podejmowania współpracy między instytucjami kultury i otoczeniem?

Metodologia. Problem podejmowania współpracy omówiono, opierając się na materiale empirycznym uzyskanym z badań sondażowych przeprowadzonych w instytucjach kultury położonych na terenie miasta Wrocławia. Czynnikiem łaczaccym badane instytucje było zorientowanie ich działań na organizację czasu wolnego dzieciom w wieku wczesnoszkolnym. Badaniami objęto wszystkie instytucje kultury dysponujące ofertą skierowaną do tej grupy odbiorców, w których do kierownictwa skierowano ankietę zawierająca pytania problemowe.

Kluczowe wnioski. Przeprowadzona analiza badań pozwala stwierdzić, iż w większości badane placówki podejmują działania o charakterze współpracy. Istnieją jednak placówki, które można ocenić jako zamknięte na współpracę z otoczeniem lub rzadko ją podejmujacce. Natura zdiagnozowanej współpracy jest uzależniona w dużej mierze od specyfiki badanej placówki kulturalnej. Wyniki badań wskazuja na potrzebę zwiększenia spektrum działań podejmowanych przez instytucje kultury na rzecz współpracy z otoczeniem.

Słowa kluczowe: organizacje publiczne, współpraca, zarządzanie publiczne, instytucje kultury. 